\section{Scientific Research Organisation in Great Britain}

IN the first A. D. Little Memorial Lecture, "Science, Industry and Government", now published in Technology Review (February 1947), Sir Edward Appleton, speaking before an American audience, reviewed British experience in the organisation of research. Success in the organisation of science in the war effort has led the public to conclude that science should play a similar part in solving the problems of peace. Ultimately the provision of work, homes, food, health and safety from aggression for all depend for solution on the maintenance of the same kind of partnership between government, science and industry which grew up during the War; and, referring to the brilliant team-work during the War, Sir Edward pointed out that the result of the policy pursued was that the research establishments of the Services were strengthened by the addition of many brilliant minds from the universities, while the research teams in industry were left intact and ready to attack, as composite units, the problems allotted to them. One of the most striking results of war-time experience in Britain was the brilliant success of university research workers in solving war problems entirely remote from their peace-time interests. University conditions appear to ensure the maintenance of the mental adventurousness and lively imagination so necessary for scientific progress; and in planning the future of the Scientific Civil Service in Britain, an attempt is being made to secure conditions that encourage these qualities.

The most successful applications of science in our war-time experience resulted from the closest possible collaboration between the men of science and the military staff ; the field in which the scientific worker can usefully operate extends far beyond the labora. tory. Free fundamental research had, however, been almost entirely in abeyance in Britain, and we must recognize the return of peace by changing our priorities. In many fields, we have been living on our scientific capital, which now stands urgently in need of replenishment. Pointing out that scientific research in the universities is of relatively modern growth, Sir Edward referred to the accepted university tradition that teachers of scientific knowledge should also advance that knowledge. Although carried out in a spirit of pure inquiry, this free fundamental research has shown a surprising capacity for being useful. The universities are also the source of the trained scientific workers for university, government and industrial laboratories, and in this connexion Sir Edward referred to the outstanding importance of the exceptional man. Most of the really great advances in science have been accomplished by small teams of workers led by a man with ideas, and Sir Edward believes that a vital task is to see that such men lack neither disciples, assistants nor equipment.

\section{Magnetic Recording of Sound}

A LeCTURE on "Developments in Magnetic Recording" was given by Mr. P. T. Hobson to the British Sound Recording Association on March 27, with demonstrations of the wire-recording machine now in produetion and available in small quantities for non-entertainment purposes. A model of a highgrade instrument shows that the technique of wirerecording has risen so rapidly in recent years that the quality of reproduction obtained can be classed as high, if not higher, than with the best disks and the Philips-Miller system. The comparative cheapness of the wire, the possibility of erasure and the immediate rewind makes magnetic recording attractive for many purposes, apart from the straight and protracted reproduction of music. Ever since Poulsen discovered the possibility of magnetic recording nearly fifty years ago, designers have been misled by the erroneous idea of the exact process of magnetization. Research by the Armour Corporation of the United States and also in Britain has led to the selection and heat-treatment of the steel wire so that a diameter of only 4 mils and a velocity of 24 in. a. second can give high-quality reproduction with a signal-to-noise ratio of some 60 decibels. The material is a stainless steel, heat-treated with a current to bring it into the austenitic condition, and with a maximum ratio of the coercive force to remanence, this being the condition for minimizing the almost complete self-demagnetization of the disk-like magnets of which the wire seems to be comprised at the highest frequencies and shortest wave-lengths with tolerable loss.

Mr. Hobson gave an exposition of the theory of such longitudinal magnetization and explained the great advantage of polarizing the magnetizing current with a large component of high carrier-frequency current, which is also used for erasing. The standard machines use reels for recording for a total of 66 minutes, but sufficient quality is left at lower speeds for a total time of eight hours. The non-entertainment machine can run at various speeds for transmitting or receiving high-speed alternating-current signals, while the proposed music-machine not only uses a capstan on which ordinary disks can be played, but also includes an ingenious mechanism which automatically wraps the wire round the capstan for recording or reproducing from wire, thus making the machine substantially foolproof. If the wire should break, a knot can be tied in it.

\section{Research in the South Pacific Area}

AN important outcome of the South Seas Conference at Canberra, January 28-February 6, 1947, attended by delegations representing the Governments of Australia, France, the Netherlands, New Zealand, Great Britain and the United States, which administer non-self-governing territories in the South Seas, was the signing of an agreement establishing the South Pacific Commission, which will seek to promote the economic and social welfare and advancement of two million people in the South Pacific. The Commission is to appoint an advisory research council of persons distinguished in fields of research within the competence of the Commission, including some full-time appointments of persons highly qualified in the fields of health and economic and social development, together with a full-time director of research. The functions of the research council include the maintenance of a continuous survey of research needs in the territories within the scope of the Commission, and making recommendations to the Commission on research to be undertaken; arranging for the prosecution of research studies approved by the Commission, using existing institutions where appropriate and feasible; and co-ordinating the research activities of other bodies working within the field of the Com. mission's activities, and availing itself, where possible, of the assistance of such bodies. The council may also appoint technical standing research committees 